This article was downloaded by: [Canadian Research Knowledge Network]

On: 18 December 2008

Access details: Access Details: [subscription number 789956502]

Publisher Routledge

Informa Ltd Registered in England and Wales Registered Number: 1072954 Registered office: Mortimer House, 37-41 Mortimer Street, London W1T 3JH, UK

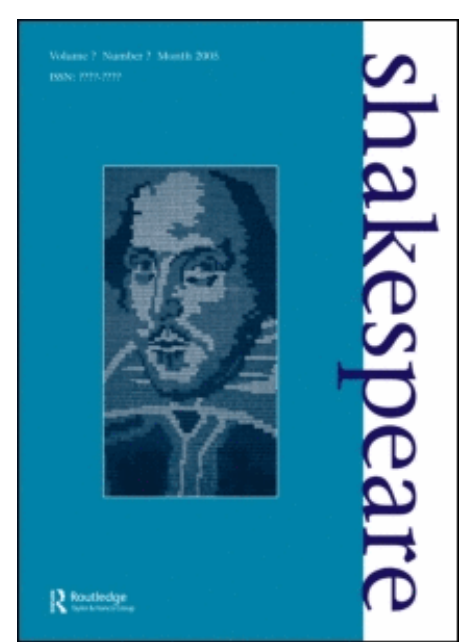

\title{
Shakespeare
}

Publication details, including instructions for authors and subscription information:

http://www.informaworld.com/smpp/title content=t714579626

\section{Past is prologue: Electronic New Variorum Shakespeares}

Paul Werstine

a King's University College, University of Western Ontario, London, Ontario, Canada

Online Publication Date: 01 September 2008

To cite this Article Werstine, Paul(2008)'Past is prologue: Electronic New Variorum Shakespeares',Shakespeare,4:3,224 - 236

To link to this Article: DOI: $10.1080 / 17450910802295070$

URL: http://dx.doi.org/10.1080/17450910802295070

\section{PLEASE SCROLL DOWN FOR ARTICLE}

Full terms and conditions of use: http://www.informaworld.com/terms-and-conditions-of-access.pdf

This article may be used for research, teaching and private study purposes. Any substantial or systematic reproduction, re-distribution, re-selling, loan or sub-licensing, systematic supply or distribution in any form to anyone is expressly forbidden.

The publisher does not give any warranty express or implied or make any representation that the contents will be complete or accurate or up to date. The accuracy of any instructions, formulae and drug doses should be independently verified with primary sources. The publisher shall not be liable for any loss, actions, claims, proceedings, demand or costs or damages whatsoever or howsoever caused arising directly or indirectly in connection with or arising out of the use of this material. 


\title{
Past is prologue: Electronic New Variorum Shakespeares
}

\author{
Paul Werstine* \\ King’s University College, University of Western Ontario, London, Ontario, Canada \\ This paper briefly reviews the history of the transformation of the New Variorum edition \\ of The Winter's Tale (WT) into an electronic edition. Then it turns to the beautifully \\ successful interface designed by Alan Galey to exploit the XML tagging of WT by Julia \\ Flanders. It ends with a look at the advantages (chiefly increased accuracy) and \\ disadvantages (chiefly the instability over time of TEI and XML, which are under \\ constant revision) of the transformation of the book edition to the electronic medium.
}

Keywords: Variorum; Shakespeare; interface

My short narrative about how the past constitutes a prologue to the splendid work now being done by Alan Galey and Julia Flanders on the Modern Language Association's electronic New Variorum edition of Shakespeare begins about 10 years ago. To be ridiculously precise, it begins at 10 a.m. on 6 December 1996, when the late Phyllis Franklin, then executive director of MLA, entered the room in the old MLA offices at 10 Astor Place in which the Committee on the New Variorum edition of Shakespeare had convened for its annual meeting. She sat down and instructed the Committee that it should plan to make the edition available on the World Wide Web (WWW) to a broad audience. It would be almost another decade before Kenneth Goldsmith, founder of UbuWeb, would opine "If it doesn't exist on the Internet, it doesn't exist" (qtd. in Perloff 3). Thus, as the last 12 years have shown, Phyllis Franklin was truly a visionary. But at that time in 1996 she seemed a visionary primarily in a negative sense. The Committee had already been discussing electronic publication off and on since the 1970s, and in the 1990s the topic had been consuming most of the Committee's agenda without our getting any closer to realizing the possibility. Nonetheless, in 2005 the latest volume of the New Variorum, The Winter's Tale, was published both as a book and electronically. My essay is some of the story of this success, as well as a presentation of some of the benefits and problems attending electronic publication.

This story first attends, in the briefest possible manner, to the development over a very long period of the New Variorum edition as a book, because its features as a book are what make its recreation in the electronic medium such a challenge. According to an opinion delivered in 1992 by Edward Mendelson of Columbia, "no program [then] existed that could handle so complicated a piece of hypertext as the Variorum in its printed form already was" (qtd. in Knowles, "New" 146). Such complication is the product of a very long process. The Latin name of the New Variorum Shakespeare is an index to the antiquity of the conception for such an edition. "Variorum" alludes to the Latin phrase editio cum notis variorum, that is, "edition with the notes of the various [editors and

*Email: werstine@uwo.ca 
commentators]", a phrase that indicates the primary purpose of each volume of the New Variorum Shakespeare edition - namely, to collect and present with all possible economy and coherence in book form what has been written by the various commentators, critics and editors on a particular Shakespeare play or on the poems or sonnets. The first edition usually called a Variorum Shakespeare was edited by Samuel Johnson and George Steevens and dates from 1773. Thereafter this 1773 Variorum was re-edited (by Johnson, Steevens, and/or Isaac Reed) and published every five or ten years until 1821, the year of Malone and Boswell's Variorum edition, which formed the basis of other, less exhaustive editions of Shakespeare into the twentieth century, according to David Nichol Smith (57). The New Variorum was inaugurated by H.H. Furness's publication of his edition of Romeo and Juliet in 1871, over 135 years ago. Furness and his son, who succeeded him as editor, brought out volumes on 19 plays by 1928. In 1933 the New Variorum Shakespeare edition became an official project of the MLA, under whose auspices 10 editions, one supplement and five supplementary bibliographies have appeared. Any edition that can still call itself new after 135 years has a long timeline.

In design these editions are masterly in exploiting the medium of the book so as to enable the editor to pack as much as possible into a volume and so as to enable the scholar to use the volume with maximum convenience. The core of each volume contains a text of the play, textual notes and commentary notes (see Figure 1). Here is the textual scholar David Greetham's description of a page in the core of an NVS:

The text-page of the Variorum is divided into three sections. The upper section presents [a very slightly edited] old-spelling reprint of the copy-text [usually, but not quite always, the earliest printed version] .... The middle section records the textual emendations to the copy-text made by previous editors of Shakespeare, and the lower section lists the commentary on the text by editors and critics. Cumulatively, a variorum can therefore present a cultural and critical history of the transmission and reception of a text, but does not ... try to create a new text. The critical commentary includes definitions from both $O E D$ and earlier editions, the citation of parallel or similar passages, and reference to critical and textual disagreements. (417)

What Greetham calls the "middle section" of the page provides a striking example of the way in which the NVS conveys a wealth of information to the glance of a scholar or critic. Take, for example, the textual note from the NVS The Winter's Tale that appears as the last such note on page 68 (the left-hand side of Figure 1). It reads "200 Observing Polixenes and Hermione. ROWE1-STAU (- CAP), KTLY-HUD2 (- DEL4)." By referring to the upper section of the page guided by the note's through line number or TLN ("200"), the reader can identify "Observing Polixenes and Hermione." as an editorial stage direction added into Leontes's accusation against Hermione "Still Virginalling / Vpon his Palme?" - although to find that the speaker is Leontes and that the subject of his speech is Hermione the reader would have to turn back several pages of the book. Then the reader could refer to the end-papers at either the front or the back of the book (see Figure 2). These list all the sigla ("ROWE1, STAU, CAP, KTLY, HUD2, DEL4") in both alphabetical and chronological order, with dates. The scholar could translate the note's sigla into the names of editors or of editions by going to the Plan of the Work in the book's prefatory matter, to which the end papers direct the scholar (Figure 3). By using the book in this way, a scholarly reader could determine from just over a full line of type that the stage direction was first added by Nicholas Rowe in 1709 (ROWE1) and that he was followed by all subsequent editors but one, up to and including Howard Staunton in 1859 (STAU); the important exception is Edward Capell in his edition of 1768 (CAP). Yet when Nicolaus Delius decided to omit the direction from his edition of 1860 (DEL2), he was 
They say it is a Coppy out of mine. Come Captaine, We must be neat; not neat, but cleanly, Captaine: And yet the Steere, the Heycfer, and the Galfe,

Are all call'd Neat. Still Virginalling

197 Tuo lines ending mine._ _ . . captain, CAP, COL, HUD1, wH1 198 not] nor POPE2 2

Wipes the boy's face Hav, ap, aur (subst) 2004

197 out of OED (prep. pbr: 13, citing this line): "Taken from." FuRNess (ed. words might.... be joined with a hyphe

Captaine] Deichron (ed. 1889): "A humourous term of affection, see [248]." Horson (1952,p. 61). Decause or "military resemblance." He supposes that Mamillius isd carries a munjed dager (f. 235). But the word also is a familiar terme soldier," in TIm. 2.2 .73 (740), where there is no military association. The CLARKrs (1879, p.

198 We . . cleanly] C. G. SMrru (1963, no. 28) finds parallels in Cato and in ind Culman, Sententae Puerles.

for borned cartle." Crosay (1878, 1966): Leontes recollects "that neat is the because the cattle, although termed neat, are anything but cleanly, An earlier effor by RUSHToN (1867, pp. 62-3) to make neat mean "dirty" is unsupported by OED. for it is given also to the calf." MARSH (1962; 1980, P. 120): Leontes "sees the 199 Heycfer] Among the dialectical forms of betfer, EDD lists beckfor (North Country) and beiffer (East Anglia and Norfolk). OED gives belcfar for the 17th $C$. (s) foul papers, the spellng is

200 Neat] $O E D$ ( $s b .2$, citing this line): "Cattle."

Virginallingl JoHsson (1755): "To pat; to strike as on the virginal." SCHMmT (1875): "Fingering." STEEvEN (ed. according to MiNSHEv (1617), the instruments are "so called because Virgins and Maidens play on them," a derivation tentatively supported by Stanley Sadie (ed.), The New Grove Dictionary of Musical Instruments (1984). Leontes thus may be struck do 50 , as WEBB (1989) indicates by the gloss " as if playing the instrument allusion to playing upon the virginals occurs in TNK 3.3.34, Fletcher's scene. Brook (1976, p. 70) finds this word an example of "functional shift," the use of one part of is found only here. For more on the part of speech. see n. 2931 .
Vpon his Palme? How now (you wanton Calfe) Art thou my Calfe?

Mam. Yes, if you will (my Lord)

Leo. Thou want'st a rough pash, \& the shoots that I haue

201 How now] SCAMmT (1875, Now): "Sometimes = how do you do? at other times = what is the matter? what are you doing here?" OED (adv. 4b): "Ellipt. for "How is it now?' Often used interjectionally." According to the Clarkes (1879, p.
$464)$, at 2167 the words are used "arousingly." C $C$. 289, 1331, 1742, 2296, 2506, and 2597.

wanton] JohNson (1755): "Frolicksome; gay; sportive." BetнEL (ed. 1956); "The sexual theme is punningly present in 'virginalling (virgin) and 'wanton' (frisk.

202 my Calfe?] OED (1c, citing this line): "A term of endearment," which DeiGHTON (ed. 1889): Emphasizing my, as at 193. GODDARD (1951, p. 650): "He is so beside himself that he is actually questioning the paternity of his own boy." It is 193, may be jocular. Boormus (ed. 1964), improbably: "There is a suggestion of 'Are you going to grow up to have horns, like your father?

204-22 Thou ... Browes] SMrri (1968, p. 317): "The speech falls ... into

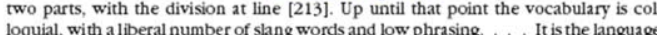
of 'blood'. In [214-22], however, a completely unique pattern exists. The language of 'grace' is invoked in an attempt to impose logic and a decorous cohesion on his thoughts." But the attempt fails. As SMrrt says (p. 318), lines 214-22 "are very dir62 ) potices "the series of starts and false starts.


this line as its first example). RANN (ed. 1787): "Pate, like a bull calf," "which Coumer forehead of a bull" Many siminootr (MS 1813-33), extends mad Pasb; a mad brain," a Cheshire word. WISE (1861, p. 155) lists pasb, "a rough head," among the Warwickshire words used by Sh. DAvis (1876) associates the word with basb, in Herefordshire "the front of the head of a bull or a pig" (EDD). SN SigR's horns are springing" is unsupported by OFD or EDD. BENDA (ed, 1825) believes the word is a Scottish term for "head," and MACKAY (1884, p. 55) connects it with a Gaelic word "signifying the brow or forehead. ... A 'rough pasb' means a brow furrowed with care." HANMER (ed. 1743- 4, 6:glos.), oddly, though followed by JoHN(175e dom." Hulurwzit (ed. 1859): Or "beard." The association with horned cattle is probably dominant, though, since these animals are closely associated with marital

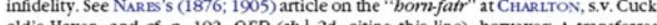
old's Haven, and c., n. 192. OED (Sb.'2d, citing this line), however, A transferred elling in his own imagined shame."

Figure 1. Pages 68-69 of Robert Kean Turner et al.'s 2005 New Variorum edition of The Winter's Tale. 


\section{EDITIONS COLLATED}

These sigka are used in textual noces to identify readings from tbe editions and retated woris Whatil ff. The form and scope of the notes are explained on p.xfy. Sigta in

\begin{tabular}{|c|c|c|c|c|c|c|c|}
\hline F1 & 1623 & $\mathrm{v} 1773$ & & $\mathrm{COL} 2$ & 1853 & NLSN & 1906 \\
\hline F2 & 1632 & (GENT & 1774) & SING 2 & 1856 & (RLTR & 1907) \\
\hline & $1663-4$ & v1778 & & DYCE1 & 1857 & ARD 1 & 1912 \\
\hline $\mathrm{F} 4$ & 1685 & (Ays1 & 1784) & wH1 & 1857 & CaM3 3 & 1931 \\
\hline ROWE1 & 1709 & v1785 & & $\cot 3$ & 1858 & (RID & 1935) \\
\hline ROW12 & 1709 & RANN & 1787 & HLL & 1859 & KIT1 & 1936 \\
\hline ROWE3 & 1714 & (AYS2 & 1790) & STAU & 1859 & (N\&H & 1942) \\
\hline PE1 & 1725 & MAL & 1790 & $\mathrm{DE}$ & 1860 & (PEN1 & 1947) \\
\hline $\mathrm{PE} 2$ & 1728 & $\mathrm{v} 1793$ & & CAM1 & 1863 & ALEX & 1951 \\
\hline & 1733 & (KEM1 & 1802) & GLO & 1864 & sts & 1954 \\
\hline $\mathrm{IEO} 2$ & 1740 & v1803 & & KILY & 1864 & PEL1 & 1956 \\
\hline HAN1 & 1743 & (KEM2 & 1811) & DYCE2 & 18 & $a \times 2$ & 1956 \\
\hline HAN2 & 1745 & v1813 & & KNT3 & 1867 & (MUN & 1957) \\
\hline WARB & 1747 & $\mathrm{v} 1821$ & & DELA & 1872 & $\triangle \mathrm{ARD} 2$ & 1963 \\
\hline (THEO3 & 1752) & (HARN & 1825) & (DYCE3 & 1875) & SIG & 1963 \\
\hline (BLAIR & 1753) & SING1 & 1826 & $\operatorname{COL} 4$ & 1875 & (K\&RR & 1967) \\
\hline THEO4 & 1757 & (VALPY & 1833) & HUD2 & 1880 & (PEL2 2 & $1969)$ \\
\hline јонх1 & 1765 & $\mathrm{KNT1}$ & 1841 & wH2 & 1883 & PEN2 & 1969 \\
\hline ЈННะ2 & 1765 & $\mathrm{~K} N \mathrm{~T} 2$ & 1842 & IRV & 1890 & EWNS & 1974 \\
\hline$C A P$ & 1768 & COL1 & 1842 & $O X P 1$ & [1891] & BEv3 & 1980 \\
\hline (HAN3 & 1770) & HUD1 & 1852 & (CAM2 & 1891) & OXF2 & 1986 \\
\hline & & & & & 1905 & BEV4 & 1988 \\
\hline
\end{tabular}

The following sigla appear in the appendix of unadopted conjectures or

\begin{tabular}{|c|c|c|c|c|c|}
\hline msing & $1632-1856$ & mGREY & $1747-66$ & $\mathrm{~m} 1790 \mathrm{bFL}$ & $1790-$ \\
\hline mF1н & $-1650 ?$ & mWARB & $1747-79$ & $\mathrm{~m} 1793 \mathrm{BOD}$ & $1793-1803 ?$ \\
\hline MFLV.a.80 & 1655-9 & $\mathrm{mF2FL} 27$ & c. 1750 & $\mathrm{~m} 1793 \mathrm{FL}$ & \\
\hline $\begin{array}{l}\text { mF1F.10 } \\
\text { MPOPE }\end{array}$ & $1700-$ & mush & c. 1754 & & 1813-33 \\
\hline $\begin{array}{l}\text { MPOPE } \\
\text { mTBY1 }\end{array}$ & -1723 & mCAP2 & 1754 & MCOLE & c. 1834 \\
\hline $\begin{array}{l}\text { mTBY1 } \\
\text { mTHEO1 }\end{array}$ & $1709-25$ & $\mathrm{mF} 2 \mathrm{FL} 21$ & $1754-65$ & mLer & $1840-65$ \\
\hline $\begin{array}{l}\text { MTHEO1 } \\
\text { mTBY2 }\end{array}$ & $-1729 ?$ & mTYR & -1767 & moot1 & c. 1840 \\
\hline $\mathrm{mTBY} 2$ & $1725-33 ?$ & mMAL1 & $1773-90$ & $\mathrm{moOL} 2$ & c. 1850 \\
\hline MLONG & $-1733 ?$ & $\operatorname{mMAL} 2$ & $1777-80$ & $\operatorname{mTAY}$ & c. 1850 \\
\hline mTBY3 & $1733-47 ?$ & $\mathrm{~m} 1773 \mathrm{FL} 3$ & $1778 ?-$ & COLNE & \\
\hline mF4TCC & $1733 ?-$ & DODD & 1780 & mool3 & $1858-78 ?$ \\
\hline $\mathrm{m} 1733 \mathrm{FL} 4$ & 1733?- & CAPN & 1783 & mStAU & $1864-74$ \\
\hline HAN & $1735-9$ & $\mathrm{~m} 1778 \mathrm{BL}$ & -1785 & MBRAE & 1877 \\
\hline roL & $1740-79$ & $\mathrm{~m} 1768 \mathrm{FL}$ & c. 1790 & MPER & $1885-19$ \\
\hline 2FL.48 & -1747 & mтоо & $1790-1812$ & mWRAY & $1891-3 ?$ \\
\hline IBY4 & $747-53$ & m1790arL. & $1790-$ & v1898 & \\
\hline
\end{tabular}

Symbols used in the textual notes

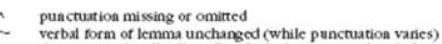

(berwera sigh) all nulfy collated eds. berwera and including those represented by the

$+\quad$ (arter a siglum) and all succecding frlly collated eds.

(-) all sigh anter the minus sign and within the parenth

\section{SIGLA AND SYMBOLS}

The sigla on the facing page are bere arranged alpbabetically. ARD: ARD1 \& ARD2

ARD 1: Moorman, 1912

ARD2: Paffiond, 1963

(Ars1, 2): Ayscough, 1784,

BEV: BEV3 $\&$ BEV4

BEV3, 4: Bevington, 1980 .

(BLARR): Bhair, 1753

cas cam1 \& cas3

CMM1: Clark, Glover. \&
Wright, 1863

(cAM2): Wright, 1891

CAM3: Wilson 1931

CAP: Capell, 1768
(CAPN): Capell, Notes, 1783

(CAPN): Capell, Nons,

COL: $\mathrm{COL1}, \mathrm{COL} 2, \mathrm{COL}_{3}$, \&

COL1, 2.3.4:

3,4 Collicr, 1842 .
$1853,1858,1875$

(COLNE): Collicr, Notes, 185

DH: $\mathrm{DH} 2 \& \mathrm{DE}$

DH2, 4: Delius, 1860, 1872

1780

DrCE: DrCE1 \& DYCE2

DrCE1, 2, (3): Dyce, 185
1864,1875

EvNs: Evans, 1974

Ff: F1, F2, F3, \& F4

F1, 2, 3, 4: Folios 1623,
1632, 1663-4, 1685

(GEVT): Genteman, 1774

GLO: Cark \& Wight, 1864

HuL: Halliwell, 1859

HuN1, 2, (3): Hanmer, 1743.

(HARN): Harness, 1825

HUD: HUD1 \& HUD2

HDDl, 2: Hudson, 1852, 1880

1967
(here): Kitrodge-Ribner.
.

(KEM): KEM1 \& KEM2
(KEM1, 2): Kemble, 1802.

1811

Krr1: Kittredge, 1936

KNT1, 2, 3: Knight, 1841.

(m1733F44): Anon., 1733?-

(m176851): Anon., c. 1790

(m1778B1): Anon., - 1785

(m1790arl): Anon, 1790-

(m1790brt): Anon., 1790-

(m1793BOD): Stcevens et
1793-1803?

(m1793F1): Anon., 1793-

Mat: Malone, 1790

(mCAL): Caldecott, 1812-33

(mCAP2): Capell, 1754

(mCOLL, 2, 3): Collicr, $\mathrm{c}$
1840, c. 1850.

(mCOLE): Coleridge, c. 1834
(mFIH): Anon., -1650?

(mFLV.a.80): Evans, 1655-9

(mF1FL10): Anon., 1700-

(MF2FL27): ANOOD., c. 1750

(mF2FL48): Anon., -1747

(mGRE): Grey, 1747-66

(mHAv): Hanmer, 1735-9

(mLTT): Lettsom, 1840-65

(mLONG): Long, -1733?

(mLtesh): Lushington, c. 1754

(mPIR): Perring, 1885-1920? (mPOPE): Pope, -1723

G): Anon., 1632-1856

(mSTAC): Staunton, 1864
(mTAD): Taylor, c. 1850

(mTE1, 2, 3, 4): Thirlby.

1709-25, 1725-33?
(MTHEO1): Theobald,
-1729?

(mTOL): Tollet, $1740-79$

(mTY): Tyrwhit, -1767

MLs): Munno, 1957

(mWARB): Warburton, 1747-

(mWrar): Wray, 1891-3? (NeH): NeilsonHill, 194

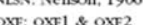

ove. Cois 18911

OXF2: Wells, 1986

PEL1: Maxwell, 1956

PEL2): Maxwell, 1969

PEN1): Harrison, 1947

Ev2: Schanzer, 1969

POPE1, 2: Pope, 1725, 1728

(RID): Ridley. 1935

(RLTR): Chambers, [1907]

ROWE: ROWE1, ROWE2, \&

ROWE1, 2, 3: Rowc, 1709,

16: Kermode, 1963

NG: SNG1 \& STYG 2

ST: Sisson, 1954

THEO: THEO1, THEO2, \&

$1733,1740,1752$,
1757

v1773, v1778: Johnson

v1785: Johnson, Steevens, \&

v1793: Steevens \& Reed

v1803, v1813: Reed

v1821: Boswell
(v1898) Furness

(VALPV): Valpy, 1833

WARB: Warburton, 1797
WH: WH1 \& WH2

wH1, 2: White, 1857, 188

Figure 2. Endpapers from Turner's edition of The Winter's Tale. 
v1793 George Steevens \& IsaAc Reed. Plays. 15 vols. 1793.1793 Vol. 7.

v1803 ISAAC REED. Plays. 21 vols. 1803, Vol. 9.

v1813 ISMC REED. Plays. 21 vols. 1813. Vol. 9.

v1821 Jumes Boswa Plays \& Poems. 21 vols. 1821 Vol 14

SING1 SAMUEL W. SINGER. Dramatic Works, 10 vols. Chiswick, 1826. Vol. 4

KNT1 Charles KNIGHT. Comedies, Histories, Tragedies, \& poems. Pictorial Ed. 55 pts. [1838-43.] Reissued in 8 vols. Pt. 30 (Comedies, vol. 2) Charies KNight. Comedies, Historles, Tragedies, $\varepsilon$ Poems. 2nd ed. 12 vols. 1842-4. Vol. 4 .

COL1 JOHN PAYNE COUER. Works. 8 vols. 1842-4. Vol. 3.

HUD1 HENRY N. Hudson. Works. 11 vols. Boston \& Cambridge, Mass., 1851-6. Vol. 4

COL2 JOHN PAYNe COLUER. Plays.

SING2 SAMUEL W. SINGer. Dramatic Works, 10 vols, Vol 4

DYCE1 ALEXANDER DYCE. Works. 6 vols. 1857, Vol. 3.

WH1 RICHARD GRANT WHITE, Works, 12 vols. Boston, 1857 66. Vol. 5.

COL3 JOHN PAYNE COUER. Comedies, Histories, Tragedies, \& Poems. "The Second Edition." 6 vols. 1858. Vol. 3. JAMEs O. HAWWEH, Works. 16 rols. 1853-65. Vol. 8 JAMES O. HALWELL. Works. 16 vols. 1853-65. Vol. 8.
HOWARD STAUNTON. Plays. 50 pts. 1856-60. Reissued HOWARD STAUNTON. Plays. 50 pts. $1856-60$
in 3 vols. 1858-60. Pts. $37-8$ (Vol. 3).

DEL2 Niconus DenUS. Werke. 7 vols. Elberfeld, 1854-[61]. Vol. 6 .

CAM1 WiLUM George CLARK, JOHN GLOVER, \& WiLUAM ALDIS WRIGHT. Works. Cambridge Sh. 9 vols. Cambridge \& London, 1863-6. Vol. 3.

GLO WIULM GEORGE CLARK \& WILUAM AIDIS WRIGHT Works. Globe Ed. Cambridge \& London.

KTLY Thoms Keightiey. Plays. 6 vols. 1864. Vol. 2.

DYCE2 ALEXANDER DYCE. Works. 2nd ed. 9 vols. 1864-7. Vol. 3.

Charies KNIGHT. Works. Pictorial Ed. "The Second Edition, Revised." 8 vols. 1867. Comedies, vol. 2.

DeL4 Nicolnus Denus. Werke. "Dritte, Revidirte Auflage." 2 vols. Elberfeld, 1872, Vol. 1

COL4 JOHN PAYNe COLIER. Plays \& Poems. 43 pts. in 8 vols. 1875-8. Vol. 3

HUD2 HENRY N. HUDSON. Works. Harvard Ed. 20 vols. Boston, 1880-1. Vol. 7.
1803

1821

1826

84

184

1842

1852

1853

1856

1857

1857

1858

1859

859

1860

1863

1864

1864

1864

1867

1872

1875

1880

xiv
Wh2 RichuRd Grant Whrte. Comedies, Histories, Tragedies, \& Poems. Riverside Sh. 6 vols. Boston, 1883. Vol. 2 .

IRV HeNRY IRVING \& FRANK MARshall. Works. Henry Irving Sh. 8 vols. N.Y 1888-90. Vol. 7 . Notes and Introd by Arthur Symons.

OXF1 W. J. CRAIG. Works, Oxford Sh

[1891]

Stratford-on-Avon, 1904-7, Vol. 4

NLSN WILUM ALLAN NemSON. Works. Cambridge Ed. Boston 1906 \& N.Y.

ARD1 F. W. MOORMAN. WT. Arden Sh.

CAM3 ARTHUR QUWHER-COUCH \& JOHN DOVER WHSON WT 1912

New [Cambridge] Sh. 1931; rev. 1950.

KIT1 GEORGE LYMAN KITTREDGE. Works. Boston.

ALEX Peter ALeXANDer. Works.

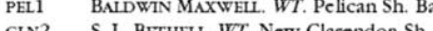

CLD2 S. L. P. PAFron. WT New Arden Sh. 1956

SIG FRANK KERMODE. WTT Signet Classic Sh

PEN2 ERNEST SCHUNZER WT New Penguin Sh

EvNs G. BurEmone Evans et al. Works. Riverside Sh

Boston.
B

BEV3 DAVID BEVINGTON. Works. 3rd ed. Glenville, Hil. Sh 1980

1986

Bev4 DAVID BEvington. The Late Romances. Bantam Books. 1988

Toronto.

The editions, books, and manuscripts listed below are also referred to. Although all editions mentioned in the textual notes have been fully collated, Although

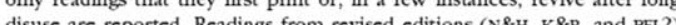

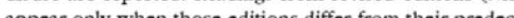

msING

MS notes in F2, S. W. Singer copy, quoted in

$1632-1856$

SING2

(1959).

-1650 ?

Garden."] Commonplace book. Folger Library.

mF1Fu10 MS notes in F1. Folger Library, Copy 10.

$1655-9$

$1700-$

Figure 3. An opening from the Plan of the Work of The Winter's Tale. 
followed by William George Clark and William Aldis Wright in their first Cambridge edition of 1863 (CAM1) and again by Clark and Wright in their Globe edition of 1864 (GLO). Nonetheless, Thomas Keightley returned to Rowe's addition in 1864 (KTLY), and was followed in doing so by all editors but one (this time Delius again in his fourth edition of 1872 - DEL4), up to and including Henry N. Hudson in his second edition of 1880 (HUD2), but by none thereafter. This note then becomes one particular piece of evidence for the view that Capell was the eighteenth-century editor most capable of independent thought. The note also contributes evidence to the opinion that Clark and Wright's rethinking in the 1860s of the Shakespeare editorial tradition was thorough, taking into consideration even the most recent editions, like Delius's second edition of 1860, as well as profoundly influential on later editorial tradition - although only after a period of nearly 20 years. I hope it will not sound like special pleading to argue that the scholarly conventions employed in the core of an NVS for arranging a paragraph's worth of information in the space of a line or so of type are a masterpiece of economy. This core is followed by a number of appendices providing in the form of excerpts, paraphrases and summaries all discussion of the play's textual problems, date, sources, criticism and history of production on stage, followed by a bibliography of all items cited. These appendices digest a great deal of material in a severely limited compass and lavishly employ crossreferences (especially to each other, to the text of the play [what Greetham calls the upper section of the core], the commentary [the lower section] and the bibliography of the edition). Altogether there are more than a thousand cross-references in an NVS.

To realize Phyllis Franklin's vision fully, we will need to find ways to transform the highly developed scholarly conventions of the book just described into the conventions of the WWW - without loss of either functionality or information - quite a challenge in view of the WWW convention that navigation of any site be intuitively obvious, that is, free of convention. In 2005 our latest volume, The Winter's Tale, was published electronically on CD-ROM in PDF (Portable Document Format). ${ }^{1}$ Of course, publication in this format is still a long way from realizing Phyllis Franklin's vision. However, there are distinct scholarly advantages to the format, and it does offer significant additional advantages over book publication alone. Chief among these advantages are basic searchability and the hypertext links of all sigla to the Plan of the Work, which identifies them; links of all citations of items in the Bibliography to the full bibliographical entries; links of all crossreferences to other places in the book itself to those very places. Thus, with the CD-ROM, a reader can navigate an NVS much faster, clicking a mouse, rather than turning pages. Hypertext links also help break through at least to some extent the thicket of scholarly conventions that limit accessibility of the NVS to the larger public; for example, one need no longer learn the distinction between editions, which are listed in the prefatory Plan of the Work, and criticism and scholarship, which are provided in the concluding Bibliography - just click the citation and be taken to the proper location. Nonetheless, it must be admitted that PDF does very little to exploit the opportunities provided by the electronic environment. However, there are problems in that environment that PDF effectively addresses. With PDF we can preserve from the distortions of browsers like Internet Explorer the integrity of NVS scholarly editing.

PDF may mean "Portable Document Format," but for the NVS it appears to mean "Protected Document Format". It is reasonable, then, to ask why it is necessary to preserve and protect the book format in making the NVS electronic, especially because of the difficulty attending the adaptation of the convention-bound book to the new conventionfree medium, as well as our inability to take much advantage of this medium by clinging to the book. The answer lies partly in the long NVS timeline mentioned before. Although the 
WWW is now about a half a generation old, dating from 1992, for nearly another whole generation the NVS volumes that are published will be ones that were undertaken before the WWW came to be. That is, these books, once published, will have been at least three or four decades in the making, conceived from the beginning only as books, not as electronic editions. A second reason for sticking to the book is its proven durability as a medium across several centuries, a medium with which the WWW will not be able to compete on the basis of longevity for several more centuries. And a third and final reason is that the enormity of human effort that goes into constructing, checking, copy-editing and proofreading an NVS edition for book publication simply cannot be duplicated in order to create a second different and born-electronic edition without bringing an already agonizingly long project to an utter halt.

Therefore our hope lies in the possibility of exploiting the potential for the electronic medium that already exists in the rigour of the well-established conventions of the book edition described above. The NVS Winter's Tale has been encoded in XML to conform to TEI under the expert direction of Julia Flanders. Thus there is the potential within this text for its display in a great variety of forms, and it is to be hoped, as is always the case with $\mathrm{XML}$, that it will retain this potential even as current software and hardware rush toward their destined obsolescence. Alan Galey has already achieved astonishing success in using the XML code for uniquely digital presentations of the NVS. He can display the three-part page of the NVS core in a number of interface modes, depending upon the particular interests of the reader. In one interface mode (Figure 4), the text of the play alone appears (i.e. the upper section of the printed page). ${ }^{2}$ In this mode, each line can be clicked in order to open in a box beside the text both the textual notes (i.e. the middle section of the printed page) and the commentary notes (i.e. the lower section of the page) associated with that particular line. If the commentary note is extensive (as is often the case in the NVS), the

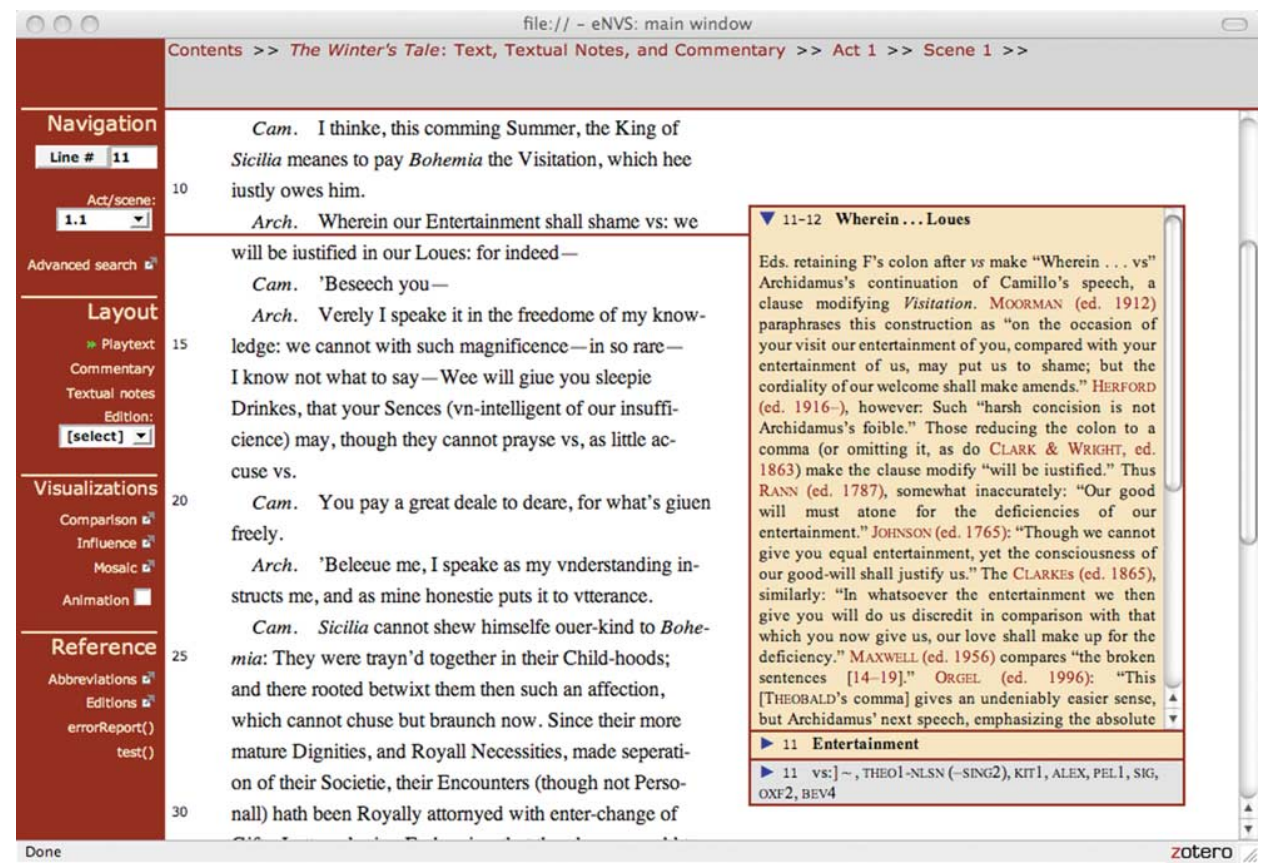

Figure 4. One interface mode of Galey's eNVS core. 
box in which it appears is scrollable so that the reader never loses sight of the line of text as $\mathrm{s} /$ he reads the commentary on it, as is often the case with the printed NVS when one must turn the page in order to finish reading the commentary note. This mode may be the most popular one because most readers approach the NVS with a view to learning all they can about a particular word, line or passage in a play. In a second interface mode (see Figure 5), designed for a reader interested primarily in the history of emendation of the text, the reader can open up beside the play text all the textual notes; thus the reader can see a great many more of the NVS's textual notes at once than in the printed book, in which the bulk of commentary notes limits to a few both the number of textual notes and the number of lines of the play text visible in a single opening. In a third interface mode (see Figure 6) the reader can choose to fill the screen with commentary notes alone, together with the lines of text to which they refer.

Galey's handling of the textual notes represents his most startling innovation. His interface treats each textual note as a data object, allowing for multiple forms of visualization rendered on the fly. The note thus can be made to appear on the screen not only in the highly compressed form quoted above but also in a much more accessible colour-coded tabular form. If one were, for example, to click on the textual note already quoted, "200 Observing Polixenes and Hermione. ROWE1-STAU ( - CAP), KTLY-HUD2 (-DEL4)", a box would open beneath the note. This box would contain two columns of cells. Each cell would contain the relevant information for a particular edition: its date, its clickable siglum and its reading in this place. The cells for editions that include the words "Observing Polixenes and Hermione." would be green, those omitting the words white. Thus there would appear at the head of the first column four white cells representing the four seventeenth-century Folios (F1-F4), all of which omit the stage direction. Then, the

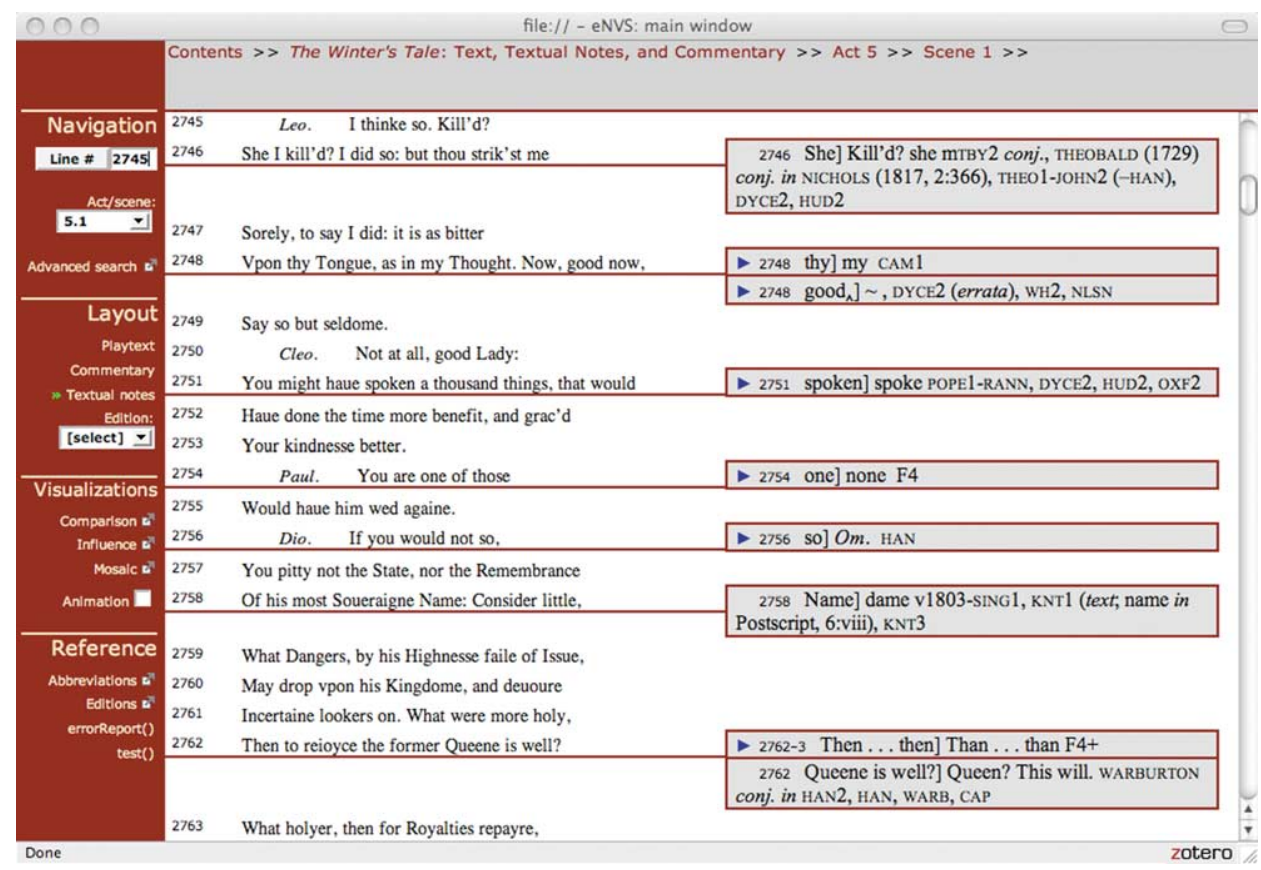

Figure 5. Another interface mode of Galey's eNVS core, with all the textual notes appearing beside the play text. 


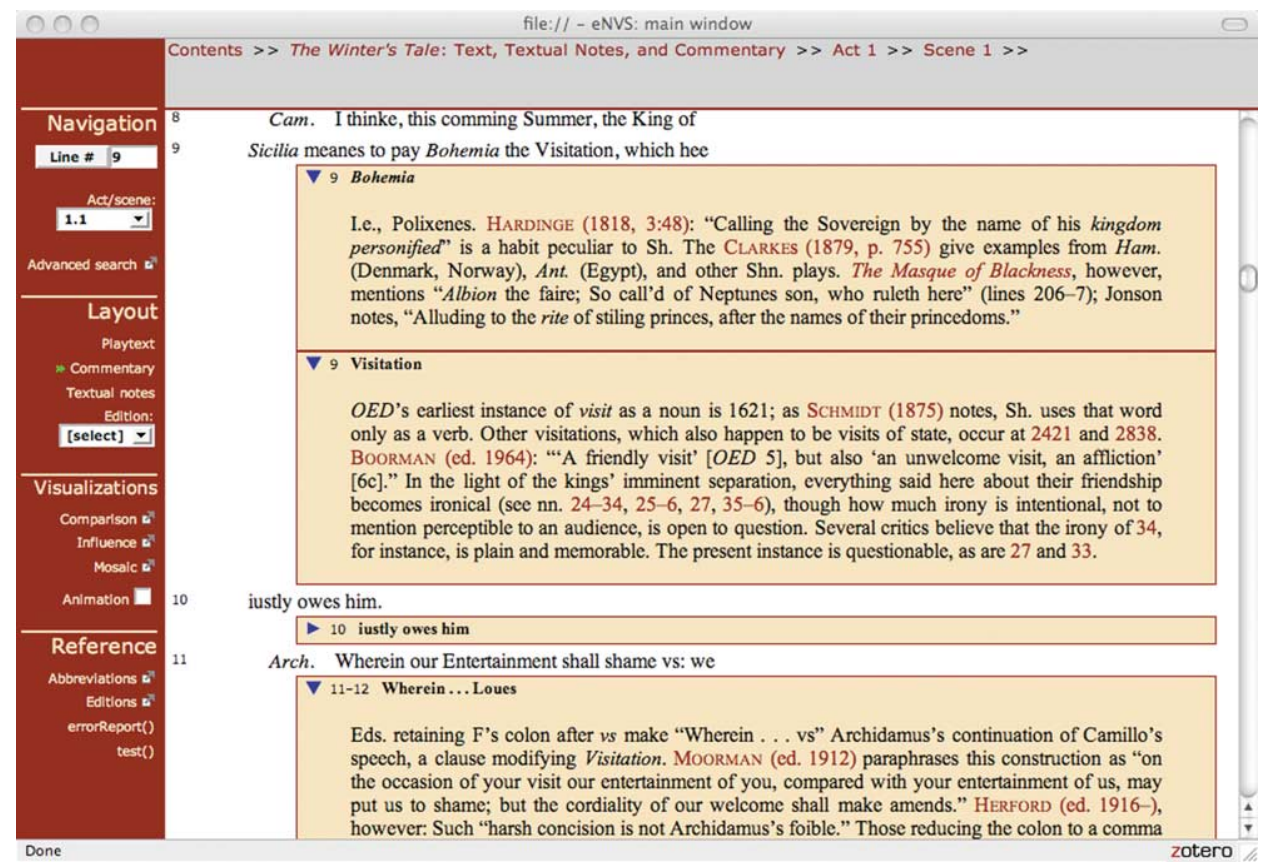

Figure 6. Yet another interface mode of Galey's eNVS core, with commentary notes appearing with the lines of text to which they refer.

fifth cell, coloured green, would represent Rowe's first edition, which introduces the stage direction for the first time. The rest of the first column would all be Rowe green - with the exception of the white cell for Capell's edition of 1768, which reads with the Folios. The second column would also begin in Rowe green, but after the first five cells it would change to Folio white, those three cells representing Delius's 1860 edition and the Cambridge and Globe editions. Thereafter would come further alternations until Folio white would take over about a third of the way down the second column, not to be displaced again. This can be seen in Figure 7, from which the information detailed incompletely in my last five sentences can be completely absorbed in much less time than it takes to read those sentences. Had there been more than a single variant in the line, Galey's interface would have provided two different visualizations. The first would have been a table of the kind just described and shown in Figure 7; the second would be a shorter table to the left, which analyses the full table by tabulating each of the variants adopted by editors and associating each variant with the sigla of the editors who chose it (see Figure 8). The interface can also automate the algorithmic labour required for large-scale visualization, as when a reader might wish to see patterns of variation and emendation that extend across an entire play rather than just a single note. Figure 9 shows the results of this process, a global view of The Winter's Tale apparatus with each textual note in the NVS edition displayed row after row. Each column after the first two (TLNs and First Folio readings or lemmata) represents an edition selected by the reader (in this case the three derivative Folios [F2, F3, F4], Pope's first edition, Capell and Malone), so that the window serves as a snapshot of the larger totality of variants. This display makes visible narratives of textual change, such as the emendation of "offend" to "offends" at TLN 1724, which persists as a green bar from F2 onward. An edition between, say, Pope and Capell might revert to the reading 


\begin{tabular}{|c|c|c|c|c|c|}
\hline 1623 & F1 & & 1857 & DYCE1 & Observing Polixenes and Hermione. \\
\hline 1632 & F2 & & 1857 & WH1 & Observing Polixenes and Hermione. \\
\hline $1663-4$ & +3 & & 1858 & COLS & Observing Polixenes and Fermione. \\
\hline 1685 & F4 & & 1859 & HAL & Observing Polixenes and Hermione. \\
\hline 1709 & ROWE1 & Observing Polixenes and Hermione. & 1859 & STAU & Observing Polixenes and Hermione. \\
\hline 1709 & ROWE2 & Observing Polixenes and Hermione. & 1860 & DEL2 & \\
\hline 1714 & ROWE3 & Observing Polixenes and Hermione. & 1863 & CAM1 & \\
\hline 1725 & POPE1 & Observing Polixenes and Hermione. & 1864 & GLO & \\
\hline 1728 & POPE2 & Observing Polixenes and Hermione. & 1864 & KTLY & Observing Polixenes and Hermione. \\
\hline 1733 & THEO1 & Observing Polixenes and Hermione. & 1864 & DYCE2 & Observing Polixenes and Hermione. \\
\hline 1740 & THEO2 & Observing Polixenes and Hermione. & 1867 & KNT3 & Observing Polixenes and Hermione. \\
\hline 1743 & HAN1 & Observing Folisenes und Hermiune. & 1872 & DEL4 & \\
\hline 1745 & HAN2 & Observing Polixenes and Hermione. & 1875 & COL4 & Observing Polixenes and Hermione. \\
\hline 1747 & WARB & Observing Polixenes and Hermione. & 1880 & HUD2 & Observing Polixenes and Hermione. \\
\hline 1757 & THEO4 & Observing Polixenes and Hermione. & 1883 & WH2 & \\
\hline 1765 & JOHN1 & Observing Polixenes and Hermione. & 1890 & IRV & \\
\hline 1765 & JOHN2 & Observing Polixenes and Hermione. & [1891] & oxF1 & \\
\hline 1768 & CAP & & 1905 & BUL & \\
\hline 1773 & v1773 & Observing Polixenes and Hermione. & 1906 & NLSN & \\
\hline 1778 & v1778 & Observing Polixenes and Hermione. & 1912 & ARD1 & \\
\hline 1705 & $\times 1705$ & Observing Polixenes and Ilermione. & 1901 & CAMO & \\
\hline 1787 & RANN & Observing Polixenes and Hermione. & 1936 & KIT1 & \\
\hline 1790 & MAL & Observing Polixenes and Hermione. & 1951 & ALEX & \\
\hline 1793 & v1793 & Observing Polixenes and Hermione. & 1954 & SIS & \\
\hline 1803 & $\mathrm{v} 1803$ & Observing Polixenes and Hermione. & 1956 & PEL1 & \\
\hline 1813 & $\mathrm{v} 1813$ & Observing Polixenes and Hermione. & 1956 & CLN2 & \\
\hline 1821 & v1821 & Observing Polixenes and Hermione. & 1963 & ARD2 & \\
\hline 1826 & SING1 & Observing Polixenes and Hermione. & 1963 & SIG & \\
\hline 1841 & KNT1 & Observing Polixenes and Hermione. & 1969 & PEN2 & \\
\hline 1812 & KNT2 & Obsorving Polixonos and Hormiono. & 1971 & EVNS & \\
\hline 1842 & COL1 & Observing Polixenes and Hermione. & 1980 & BEV3 & \\
\hline 1852 & HUD1 & Observing Polixenes and Hermione. & 1986 & OXF2 & \\
\hline 1853 & COL2 & Observing Polixenes and Hermione. & 1988 & BEV4 & \\
\hline 1856 & SING2 & Observing Polixenes and Hermione. & & & \\
\hline
\end{tabular}

Figure 7. Colour-coded tabular form of the data.

"offend," - none does though - but the unbroken green indicates continuity among the editions chosen. In another example, we can see that at TLN 1782 the word "the", which was printed in the first three Folios, changed to "thy" in the Fourth Folio (with the rightangle arrow indicating that F4 introduced this emendation into the editorial tradition), persisted as "thy" through Pope, and changed back to the First Folio's "the" in Capell and Malone. Using this visualization a reader can formulate and answer broadly scoped questions: did Malone, for example, tend to depend on Capell? Which of Pope's textual innovations still show up in later editions like the 1986 Oxford Shakespeare? With this table any reader - not just a scholarly reader accustomed to reading textual notes - can see at a glance the shape of the editorial tradition in this place. Thanks to Galey's innovative interface that exploits Flanders's XML tagging, it is still possible for NVS editors to work single-mindedly towards publication in book form following the many strict conventions of the series because their books, once the conventions are rendered in the XML tagging, can be transformed out of their conventions into the convention-free WWW mode.

I want to conclude by turning to a question raised in 2002 by my co-general editor Richard Knowles concerning "how ... electronic publication [may] affect the future of the Variorum" ("New" 147). Already, I can report, electronic publication is affecting the Variorum. The most obvious and immediate effect of such publication is that it makes an 


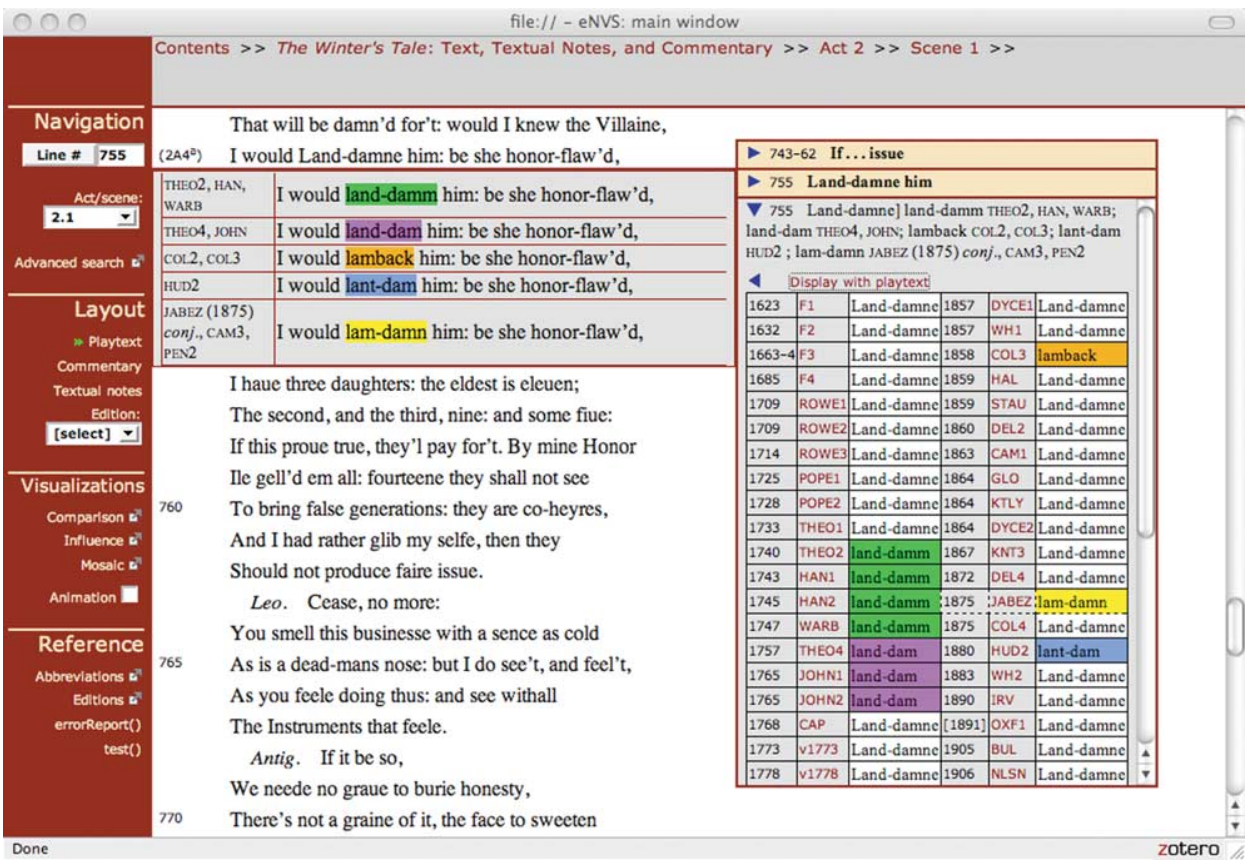

Figure 8. Colour-coded tabular form of the data, showing variants adopted by editors, and associating each variant with the sigla of the editors.

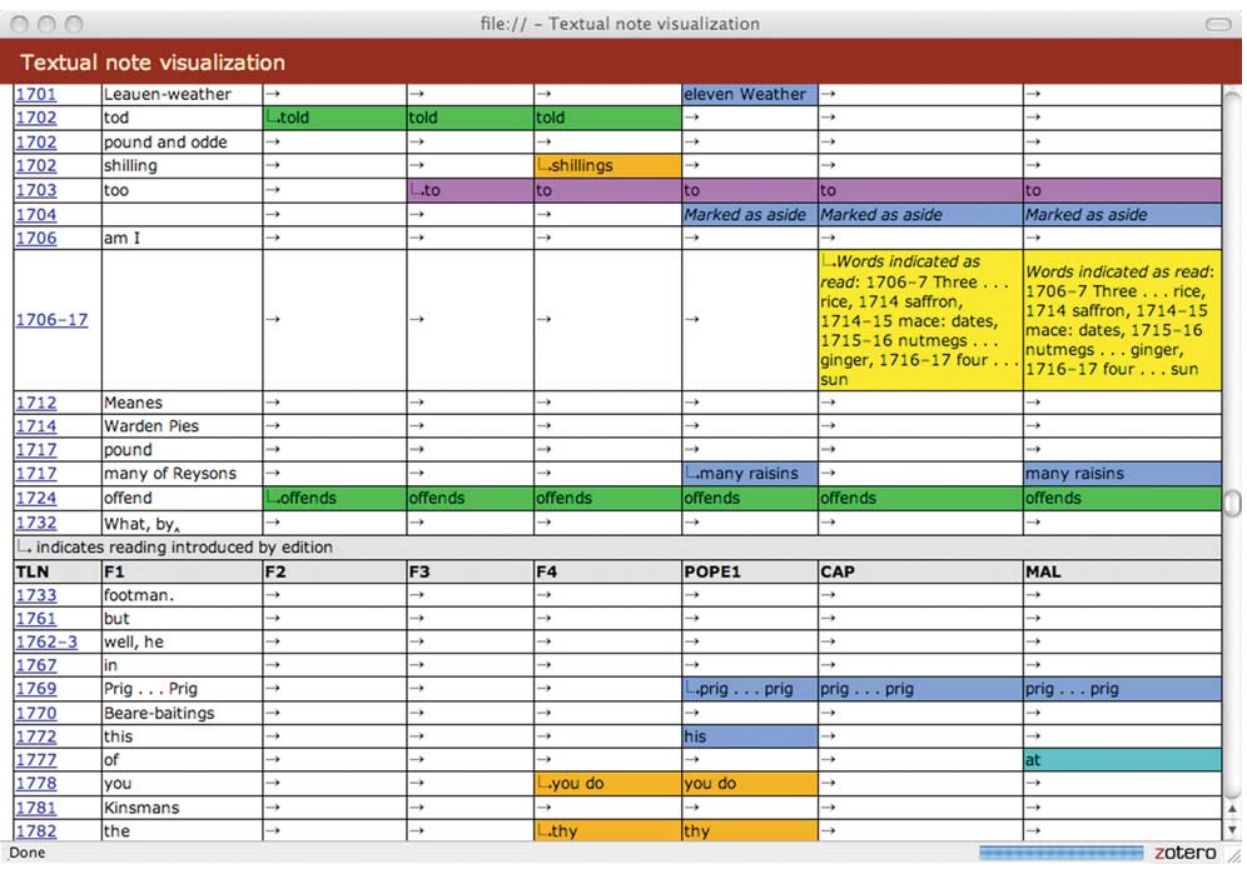

Figure 9. A global view of The Winter's Tale apparatus. 
edition more accurate. Let me explain. Long before anyone could imagine such publication, MLA, as the Variorum's publisher, had put in place procedures to ensure a very high standard of accuracy. MLA appoints general editors and charges them with the task of exhaustively checking each manuscript, making suggestions for revisions and checking proofreading. These general editors, in turn, use all their powers of persuasion on the distinguished scholars who serve on the MLA Committee on the NVS and on other scholars to join in the checking of manuscripts and the suggestion of revision. Once this stage is complete, manuscript editions then go to the MLA copy-editors, who are legendary for their rigor, and their rigor became all the more rigorous once they began receiving the manuscript in both electronic and paper form. Nonetheless, the experience of the past year has shown that for sheer rigor the process of XML tagging outdoes all procedures earlier put in place. Thus, as Julia Flanders has continued to tag ever more richly the 2005 New Variorum Winter's Tale, she has turned up some errors in the book publication to be corrected in future electronic publication of the edition that will supersede the existing CD-ROM.

There are advantages and disadvantages to the discovery of such errors. The advantages are self-evident, of course, because all editing is the quest for accurate reproduction of text, and therefore you may well be appalled that I, an editor and a general editor, should say that there could be any disadvantages to the achievement of a more correct publication. But disadvantages there are if one is concerned with the progress towards completion and publication of new volumes in the series. As the encoding of The Winter's Tale was being perfected, The Comedy of Errors was at press; Richard Knowles's monumental edition of King Lear was virtually done, and both of us were dying to see it published. Instead, time was being spent on correcting The Winter's Tale. I looked back with envy to the experience of the senior Horace Howard Furness, who achieved so much, in part by not looking back, as he wryly indicates in one of his surviving letters, this to a Dr Butler, who has found alleged errors in Furness's Hamlet:

Dear Dr. Butler: When last I had the pleasure of hearing from you, you asked me sundry questions about "Hamlet," which I should have been glad to answer if I could. Doubtless the errors which you pointed out were downright blunders, springing from what Dr. Johnson pluckily confessed to be "pure ignorance". Time was when the sight of such would have cooled my senses like a night shriek, and my fell of hair would have roused and stirred, but I have grown so accustomed to them that at the hearing I can smile \& smile and continue to be the villain with entire serenity. After I have finished a play my interest in everything connected with it but its beauty and its charms, which nothing can wither, utterly dies out. Look at it again I cannot. So I find it more comfortable to say "don't shoot, I'll come down". (qtd. in Knowles, "Philadelphia" 98)

But, as we began to publish the Variorum electronically, we had to look again at The Winter's Tale, in spite of my grousing. We needed to finalize the encoding procedures for future and perhaps even past volumes in the series. And we can anticipate a future of not only looking again then at the content of NVS editions when encoding difficulties identify errors that escaped into print, but also looking back over and over again at the encoding itself, as it continues to be developed. So far I have been speaking of XML (eXtensible Markup Language) and TEI (the Text Encoding Initiative) as if they were fixed and stable entities. Indeed they have usually been conceived and presented as such because they were devised precisely to prevent scholarly work in the electronic medium from falling prey to the obsolescence of endlessly evolving software and hardware. However, as Paul Eggert, writing with a number of his colleagues, points out, both XML and TEI are themselves perpetually under development: "When writing for this chapter began, the P4 version of 
the TEI ... had just been released. Now, the technology has progressed such that XML is the requisite language and the P5 version of the TEI ... is almost upon us" (276 5n.) Thus as markup language and document type definitions change, someone will have to look again at the markup decisions that are now being made in order to keep the electronic New Variorum Shakespeares current as electronic texts. I see myself getting caught up in an endlessly recursive loop of the kind I would create in trying and failing to write a program in an early computer language called SNOBOL about 35 years ago. Such are some of the advantages and disadvantages of electronic NVS publication.

\section{Notes}

1. My narrative elides a crucial incident in the development of an electronic NVS, namely the involvement of Professor Gregory Crane of Tufts University, the classicist editor-in-chief of the Perseus Project and a pioneer in humanities computing at Harvard in the 1980s. After initially volunteering his expertise to MLA, Crane conclusively demonstrated that it would be possible to have an electronic Variorum by creating an electronic text of an already published volume, encoding it in detail in Standard General Markup Language (SGML) to conform to the Text Encoding Initiative (TEI), the standard for encoding texts in the humanities - a huge amount of work. It is quite impossible to overstate how much the New Variorum Shakespeare remains in Greg Crane's debt. For a very early vision of what an electronic NVS might be, see Brockbank.

2. All images of the eNVS interface included here are from an unpublished prototype, and do not necessarily represent the eNVS interface or content as it will appear upon publication.

\section{References}

Brockbank, Philip. "Towards a Mobile Text." The Theory and Practice of Text-Editing: Essays in Honour of James T. Boulton. Ed. Ian Small and Marcus Walsh. Cambridge: Cambridge UP, 1991. 90-106.

Eggert, Paul, Phill Berrie, Chris Tiffin and Graham Barwell. "Authenticating Electronic Editions." Electronic Textual Editing. Ed. Lou Burnard, Katherine O'Brien O'Keeffe and John Unsworth. New York: MLA, 2006. 269-76.

Greetham, David. Textual Scholarship: An Introduction. New York: Garland, 1994.

Knowles, Richard. Rev. of The Philadelphia Shakespeare Story by James M. Gibson. Shakespeare Quarterly 43 (1992): 97-99.

_. 'What's New in the New Variorum?'. The Shakespearean International Yearbook 2 (2002): 14349.

Perloff, Marjorie. 'Teaching in the Wired' Classroom. MLA Newsletter 38.4 (2006): 3-5.

Shakespeare, William. Plays. Ed. Samuel Johnson and George Steevens. 10 vols. 1773.

—. Plays. Ed. Samuel Johnson and George Steevens. 10 vols. 1778.

—. Plays. Ed. Samuel Johnson, George Steevens and Isaac Reed. 10 vols. 1785.

—. Plays. Ed. George Steevens and Isaac Reed. 15 vols. 1793.

—. Plays. Ed. Isaac Reed. 21 vols. 1803.

Plays. Ed. Isaac Reed. 21 vols. 1813.

Plays and Poems. Ed. James Boswell [and Edmond Malone]. 21 vols. 1821.

Romeo and Juliet. A New Variorum Edition of Shakespeare. Ed. H. H. Furness. Philadelphia: Lippincott, 1871.

- The Winter's Tale. A New Variorum Edition of Shakespeare. Ed. Robert Kean Turner and

Virginia Westling Haas. New York: Modern Language Association, 2005.

Smith, David Nichol. Shakespeare in the Eighteenth Century. Oxford: Clarendon, 1928. 